\title{
What do we know about some of the most conspicuous scorpion species of the genus Tityus? A historical approach
}

\author{
Wilson R. Lourenço
}

\begin{abstract}
In the present study, comments are proposed on historical aspects of the most conspicuous scorpion species of the genus Tityus found in Brazil. Both Tityus bahiensis (Perty) and Tityus serrulatus Lutz \& Mello are better known for their infamous reputation of noxious species. However, the original discovery and description of both species are associated with interesting historical episodes. A short comment is also provided on Tityus costatus (Karsch), the species possibly involved in the first record of a scorpion incident in Brazil.
\end{abstract}

Keywords: Scorpion, Tityus, Noxious species, Historical aspects

\section{Introduction}

Even if non-scientists may consider scorpions fascinating animals, their interest is in general limited to the bad reputation of these animals as "killers of men". Nonetheless, a limited number of species - probably no more than 50 - are actually implicated in serious or lethal incidents. Indeed, this relatively small number of species possesses venoms with potent toxins, capable of killing humans. However, it is true that these infamous scorpion species are responsible for an important number of human deaths every year, which is only surpassed by those caused by snakes and bees $[1,2]$.

Most deadly species belong to the family Buthidae C. L. Koch. Nevertheless, species belonging to at least two other families, Scorpionidae Latreille and Hemiscorpiidae Pocock, also include a few other scorpions that may pose threat to humans.

The origin of mammal-specific toxins appears as an important issue in scorpion evolution. Old World lineages of Buthidae with very potent neurotoxic venom, such as the genera Androctonus Ehrenberg and Leiurus Ehrenberg, share separate mammal- and insect-specialized neurotoxins, which are specific for $\mathrm{Na}+$ channels [2]. Inversely, New World genera, including Centruroides Marx and Tityus C. L. Koch, have potent toxins acting on both

Correspondence: arachne@mnhn.f

Département Systématique et Evolution, Muséum national d'Histoire naturelle, UMR7205, CP 053, 57 rue Cuvier, Paris 75005, France mammals and insects. As an example, it was showed that one of the most potent anti-mammal toxin from Tityus serrulatus venom, called TsVII or Ts $\Upsilon$, is also highly effective against insects [3]. It is quite possible that the separate mammal-specific $\mathrm{Na}+$ toxins could have evolved during aridification of the Palaearctic in the Tertiary period, when one of the most important selective factors was rapid spread of small burrowing mammals (mostly rodents) in arid landscapes. Such newcomers to the scorpion environment, rodents would be direct competitors for space (burrows) and important nocturnal predators, as many of them are today [4]. Such pressure explains emergence of specific mammaltargeting toxins, used for defense not for hunting [5].

The family Buthidae comprises around 100 different genera - some currently extinct - and more than 1000 species, corresponding to $50 \%$ of all presently known scorpions. Among these genera, the Neotropical Tityus is by far the most conspicuous one, with near to 220 described species. Only two other genera of buthids show almost equally important numbers, Ananteris Thorell and Centruroides Marx, each with approximately 80 described species.

The aim of this work is to provide some information about the genus Tityus, in general and about some of its most remarkable species in particular. The subject is addressed in the form of a historical approach. The targets are readers who possibly use these organisms in their 
own research, but are not aware of their biological diversity. For this reason, both the text and illustrations are prepared to ensure clarity, accuracy and unambiguous communication, hopping that in this way the matter may be accessible to a broad audience.

\section{The genus Tityus C. L. Koch, 1836}

The genus Tityus was first created by C. L. Koch in 1836 [6] having as type species, by monotypy, Scorpio bahiensis Perty, 1833 [= Tityus bahiensis (Perty, 1833)]. This means that when Perty [7] described the species Scorpio bahiensis, he placed it in the old genus Scorpio Linnaeus, 1758. In fact, Scorpio is the original genus within the order Scorpiones, and subsequently to Linnaeus' work [8], many other species were accommodated in it. However, with the advance of scorpion taxonomy, only Scorpio maurus Linnaeus, 1758, the original species described by Linnaeus [8] was maintained in this genus.

The type locality indicated by Perty [7] for Scorpio bahiensis [= Tityus bahiensis (Perty, 1833)] was "Habitat prope Bahiam", presumably in Brazil, since the material he studied was originally collected during the early $19^{\text {th }}$ century expedition performed in this country by J. B. von Spix and C. F. Ph. von Martius. This locality remains, however, extremely imprecise. I will return to this point in the next section dedicated to Tityus bahiensis.

Since the creation of the genus Tityus, a large number of new described species was placed in it. Consequently, early revisions concerning the status of different species proved to be a need. A pioneer work is the one produced by Karl Kraepelin [9] in his Das Tierreich. This contribution was important because it was carried out in the context of a world revision of all scorpions known up to that date. Although this contribution was extremely valid at that point, covering all the 34 known species of Tityus, it could not be final. In fact, for several of these species Kraepelin [9] could only count on very limited samples that invalidated any analysis of the stability or variability of the taxonomic characters used by him.

Subsequently to Kraepelin's contribution [9], new species and subspecies were described in a fast pace, leading to the necessity of new revisions. Besides, having into account the increasing complexity of the genus Tityus, several authors indicated the need to divide it into several groups of species, in some cases, artificially. Kraepelin [10] had already stated that the genus Tityus was the most complex among the American genera of scorpions owing to its abundance of species and the difficulties to find useful characters allowing the definition of natural groups.

He attempted himself to create three groups of species using the pigmentation pattern as a guide. Large size species with blackish-brown pigmentation (group cambridgei), species of moderate size with dark longitudinal stripes (group bolivianus) and species of small size with variegated pigmentation (group columbianus). Unfortunately, he observed a degree of variation in pigmentation patterns and reached the conclusion that this character was not entirely satisfactory. However, at the same time, he stated that he could not find other characters!

Following the work of Kraepelin, other authors attempted to revise the genus Tityus. Mello-Campos [11] proposed an identification key to the species, without, however, any division of the genus in natural groups of species. More solid attempts to divide the genus in groups of species finally come in the publications by Mello-Leitão $[12,13]$ and particularly in his monographic work on all South American scorpions published in 1945. In that study, Mello-Leitão [14] proposed a synthesis of all his previous results and the genus Tityus was divided into 15 Formenkreise (what literally means 'circles of morphs' or natural groups). Subsequently, from 1945 until 1975, numerous papers on the genus Tityus have been published, but no change to this classification was proposed.

The matter concerning groups of species - or sometimes complexes - within Tityus began to be discussed again by the end of the 1970s, in particular by Lourenço [15-21]. Nevertheless, any attempt to proceed with a global revision of the genus proved to be extremely complicated, mainly because of the constant increase in the number of new species as observed by Lourenço [22-27]. A major attention was then dedicated to the interpretation of the observed patterns of distribution and differentiation of several groups of species [28-32]. At the same time, the number of new described species has experienced a constant increase [33-40]. Consequently, the number of described species of Tityus currently reaches almost 220, which is far from being final.

By the early 2000s, the issue on the division of the genus Tityus in groups of species was discussed again and to a certain degree Lourenço [34] restored the proposition of Kraepelin [10], by retaining three major groups of species, based mainly on pigmentation patterns, but also on some morphological characteristics. Each of these groups was named after the oldest species belonging to the group, which achieved the following results: species group Tityus clathratus, species group Tityus bahiensis and species group Tityus asthenes. Two other new insights were equally proposed in this period. The description of the new genus Caribetityus Lourenço for the Tityus species distributed in the Greater Antilles, an issue not always accepted by other authors, and the proposition of a new species group for some particular species of Tityus found in the Amazon canopy [41-43].

Considering all these novelties, as well the polemics among several authors, I finally decided to propose a division of the genus Tityus in several subgenera. The 
objective was to bring further stabilization to the classification of the group [44]. The genus Tityus was than divided into five subgenera. Three of them were based on already available genus-group names. Two new subgenera were created: Archaeotityus Lourenço to accommodate the species previously associated with Tityus clathratus group, and Brazilotityus Lourenço that accommodates some Amazonian canopy species. The composition of the genus Tityus in five subgenera remains as follows: Archaeotityus Lourenço comprising the Tityus clathratus group of species; Tityus C. L. Koch containing the Tityus bahiensis group of species; Atreus Gervais composed of the Tityus asthenes group of species; Caribetityus Lourenço encompassing several Tityus species of the Greater Antilles; and Brazilotityus Lourenço comprising the Tityus adisi group of species. My decisions concerning the composition of the genus Tityus are still a matter of polemics among certain authors and are rejected by others. Nevertheless, on account of the complexity of this group of scorpions, this decision appeared as fundamental. The Tityus species considered in the following sections belong all to the subgenus Tityus.

\section{Tityus bahiensis Perty, 1833}

Tityus bahiensis (Fig. 1) was described by Perty in 1833 [7] as Scorpio bahiensis [= Tityus bahiensis (Perty, 1833)]. According to the summarized biography proposed in Papavero [45], Joseph Anton Maximilian Perty was born in Ohrnlau (Duchy of Anspach) in 1804, and died in 1884. He studied medicine and natural sciences in Landshut and Munich. Afterwards, he joined the
Faculty of Sciences of Munich and was in charge of the organization of part of the zoological collections of the city's Academy of Sciences. Among the valuable collections of the academy, there was the one brought home by Drs. Johann Baptist von Spix and Karl Friedrich Philip von Martius from their long journeys in Brazil, financed by King Maximilian Joseph I. The results of Perty's studies of this collection were published in a large folio, from 1830 to 1833 (including the description of Scorpio bahiensis in 1833). In 1833, Perty was named professor of the Academy of Berne in Switzerland and transferred to the University in the next year. He became also the Dean of the University from 1837 to 1856.

As already mentioned, the type locality indicated by Perty [7] for Scorpio bahiensis [= Tityus bahiensis (Perty, 1833)] was "Habitat prope Bahiam", presumably in Brazil since the material he studied was originally collected during the early $19^{\text {th }}$ century expedition performed in the country by J. B. von Spix and C. F. Ph. von Martius. This locality remains, however, extremely imprecise and led to subsequent misinterpretation.

Another point of interest is the fact that Scorpio bahiensis (= Tityus bahiensis) was the very first Brazilian scorpion to be described. It was later transferred to the genus Tityus by Koch [6]. The type locality indicated by Perty [7] as "Bahiam" does not really mean that the type locality is from the state of Bahia, as incorrectly suggested by several authors and in particular by Mello-Leitão [14]. In fact, the original range of distribution of this species does not include Bahia (Fig. 2). The specimen collected by Spix and Martius,

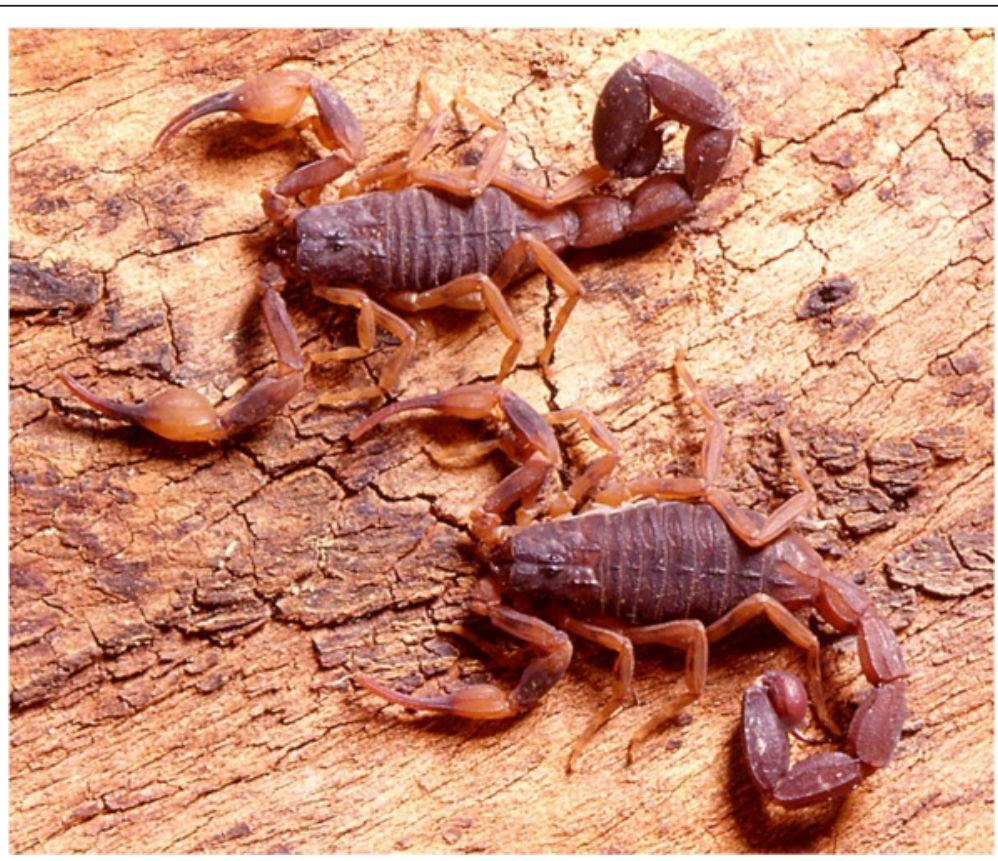

Fig. 1 Male and female of Tityus bahiensis from the state of São Paulo, Brazil 


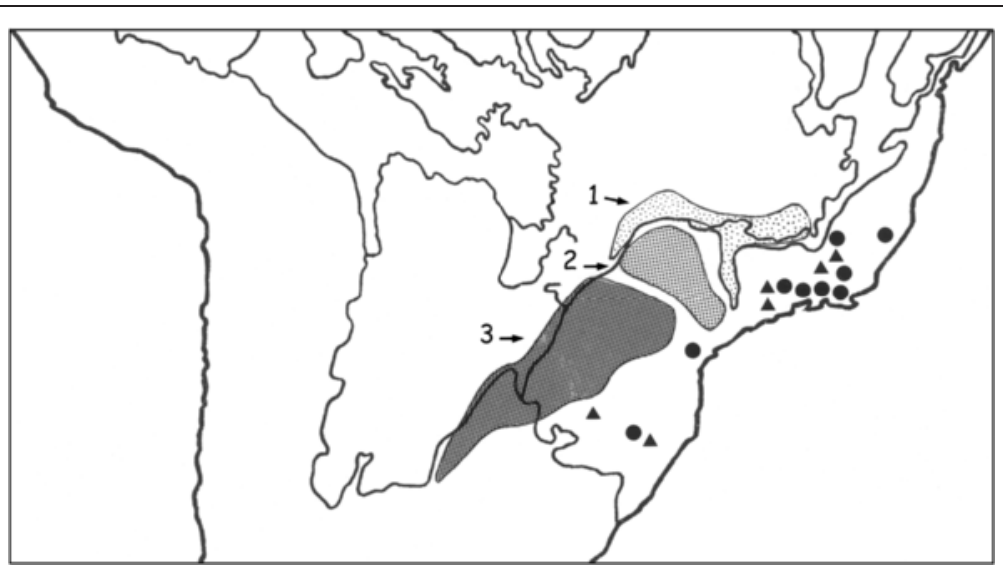

Fig. 2 Map of the South and Southeast regions of Brazil showing the distribution of Tityus bahiensis. Numbers 1 to 3 indicate northern and southern morphs. Tityus costatus: trifasciata form $(\bullet)$ and maculata form (

used in the original description of T. bahiensis, was deposited in the Zoologische Staatssammlung, Munich, Germany, but was destroyed during World War II. Consequently, any verification of the characteristics of the original specimen is therefore impossible. Lourenço [17] observed that individuals from the northern range of distribution presented differences in the pattern of their pigmentation when compared with those from the southern part of the range (Fig. 3). At first, I believed that different species were involved. However, further investigation across the whole gradient indicated that $T$. bahiensis is a polymorphic species.

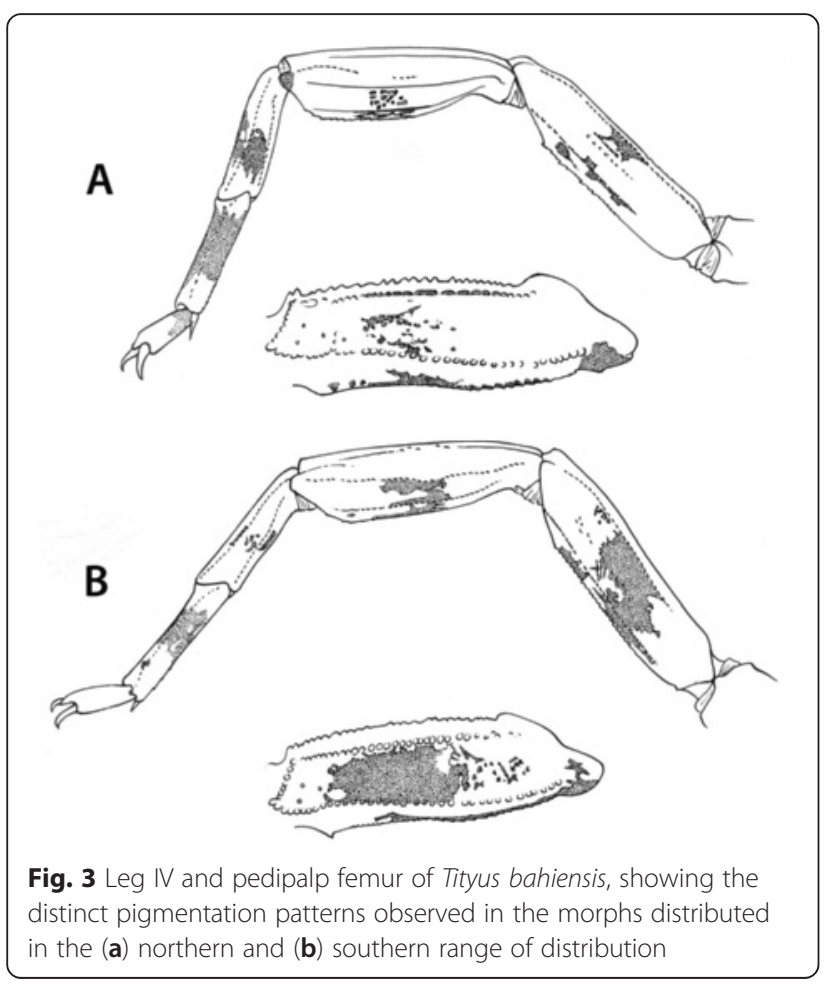

Even if the original specimen used in the description is destroyed, it was very precisely illustrated in colors, both by Perty [7] and C. L. Koch [6] (Fig. 4). These original pictures suggest that the original specimen corresponds rather to the forms found in the southern range of distribution of the species.

The description of the journey of Johann Baptist von Spix and Karl Friedrich Philip von Martius in Brazil may bring some clarification about sites from where the original specimen of T. bahiensis was possibly collected. Parts of this text, as reported in Papavero [45], are presented below.

The Bavarian naturalists Karl Friedrich Philip von Martius (born 17 April 1794 in Erlangen, northern Bavaria; died in Munich, 13 December 1868) and Johann Baptist von Spix (born 9 February 1781 in Höchstadt; died 14 March 1826 in Munich), after some weeks in Rio, where they made the acquaintance of Krusenstern and Langsdorff, decided to initiate their trip through Brazil. Through Baron von Neveu they obtained permission to enter the Brazilian Provinces. They collected in the city of Rio de Janeiro (Laranjeiras, Corcovado, Aqueduto, Fonte da carioca where the English Consul, Mr. Chamberlain, an amateur entomologist, had a coffee plantation -, Tijuca, Botafogo, Jardim Botânico). Invited by Langsdorff, they spend some days at the Farm Mandioca, and continued for a distance on the road to Minas Gerais, to a farm not too far from the Rio Paraíba. Upon their return to Rio, informed by Count von Wrbna that they could not stay in Brazil for more than two years, they decided to go immediately on their expedition. After acquiring mules for the transportation of the equipment, they went through Itaguai (13 December 1817), Areais (already in the Province of São Paulo), Lorena, Guaratingueta, Aparecida, Pindamonhangaba, 


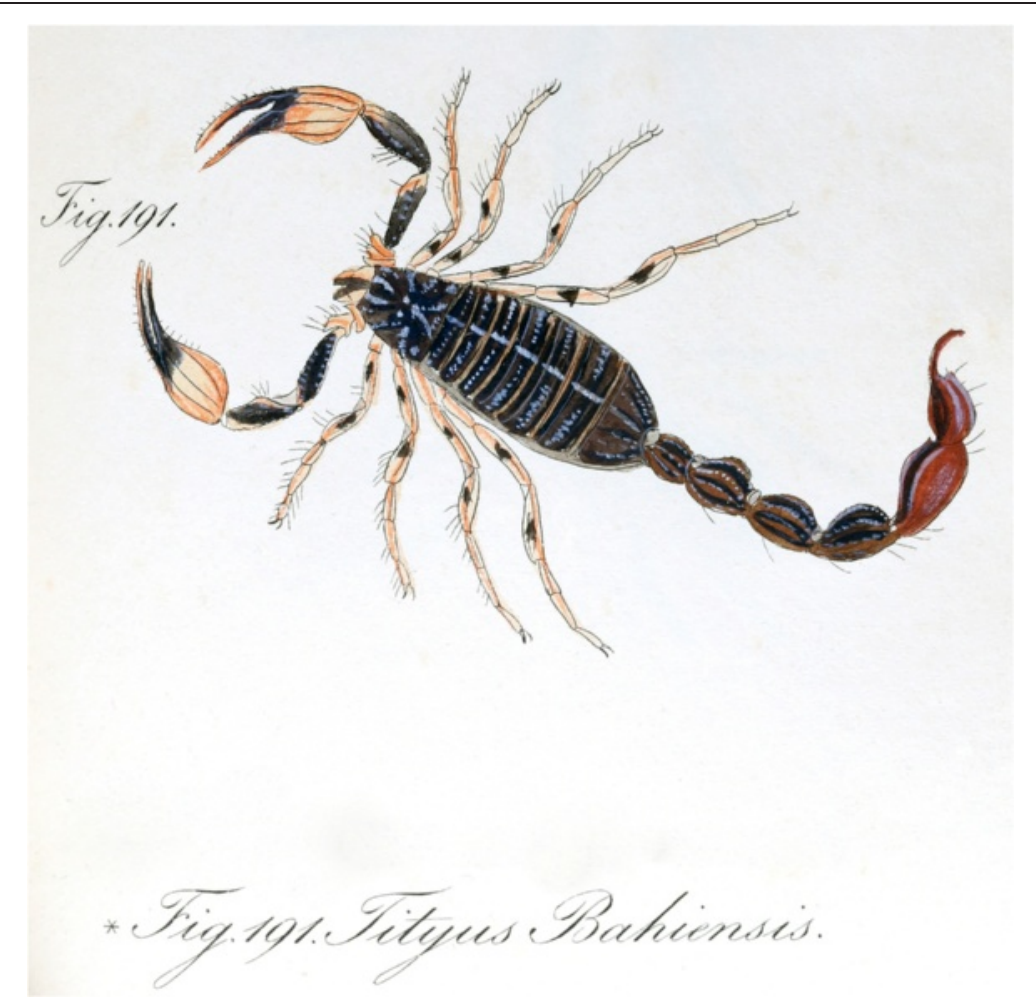

Fig. 4 Color illustration of Tityus bahiensis presented in the original publication by C. L. Koch [6]

Taubaté, Jacareí, Mogi das Cruzes, arriving in the City of São Paulo on 31 December 1817. In São Paulo, they met Count von Wrbna, Thomas Ender, Prince von Thurn und Taxis, and Count von Palfy, who had come with the Archduchess' train. Leaving São Paulo on 9 January 1818, they proceed by way of Cotia, São Roque, Sorocaba (whence they sent collections of natural history to São Paulo and Rio), Ipanema (now Varnhagen) Porto Feliz, then returned to Sorocaba, and proceeded to Itu, Jundiaí, and Atibaia, all in the Province of São Paulo. Entering Minas Gerais, Spix and Martius journeyed through Camanducaia, crossed the Rio Sapucaí, continued along São Gonçalo (do Sapucaí), Campanha (14 February, 1818), crossed the Rio do Peixe and the Rio Grande, passing by São João del Rei, and arrived at the then capital of the Province of Minas Gerais, Vila Rica (Ouro Preto). From Vila Rica they went to visit a village of the Coroado Indians, and afterwards continued their trip via Mariana (21 April 1818), whence they visited the Serra do Caraça, and returned on the $28^{\text {th }}$ to Vila Rica. Through the Governor, Manuel de Portugal e Castro, they dispatched the collections gathered in the itinerary between Sorocaba and Vila Rica. On 1 May 1818, they left the capital of the Province, and went on to Sabará, Caeté (at the time also called Vila Nova da rainha), Vila do Principe
(Sêrro), Tejuco (Diamantina), Fanado or Bom Sucesso (presently Minas Novas), Montes Claros, and Contendas (Brasília de Minas), where they remained for some time, for that region was very rich in zoological specimens, and left on 12 August 1818. Following a N-NE direction, they crossed the Rio São Francisco and the Rio Carinhanha, entering the present State of Bahia (at the time a part of the Province of Pernambuco) [...] [45].

The long expedition of Spix and Martius reached the present states of Bahia, Piauí and Maranhão, after they got permission to visit the Province of Grão-Pará. Their research was carried out in many regions of the present states of Pará and Amazonas and their journey in Brazil lasted until 13 June 1820, when both embarked on the ship Nova Amazona back to Europe. Their collections, sent to Munich, via Hamburg, consisted of 3381 species of animals of which 80 belonged to Arachnida (including the specimen of T. bahiensis).

Only the first part of their expedition, covering the states of São Paulo and Minas Gerais, may be related to the collection of the original T. bahiensis. However, the colored illustrations supplied by both Perty [7] and C. L. Koch [6] (Fig. 4) correspond quite well to the forms found in the southern range of distribution of the species. Therefore, it can be suggested that the original 
specimen was collected in one of the visited sites in the state of São Paulo.

Morphologically, Tityus bahiensis is well known. The following general diagnosis can be proposed: scorpions of medium to large size, ranging from 55 to $68 \mathrm{~mm}$ in total length, and dark brownish general coloration with reddish-yellow legs and reddish-brown pedipalps. The presence of dark spots on the pedipalps and legs is more marked in specimens from the southern range of the population, i.e. Argentina, Paraguay, and São Paulo state in Brazil, whereas those from certain parts of the states of Goiás and Minas Gerais have only small spots (Fig. 3). Metasomal segments I to III are usually reddish-brown, whereas IV and V are darker, blackish-brown. Dentate margins of pedipalp-chela fingers are composed of 17 oblique rows of granules, the subaculear tooth is strong and spinoid, and their pectines have 18 to 23 teeth. Their geographical distribution includes the Brazilian states of Minas Gerais, Goiás, São Paulo, parts of Mato Grosso do Sul and Paraná; as well as Argentina and Paraguay.

\section{Tityus serrulatus Lutz \& Mello, 1922}

In a short note devoid of any illustrations, Lutz and Mello [46] described five new species of buthid scorpions, among them Tityus serrulatus (Fig. 5), a medium-sized yellow scorpion. To this new species, they indicated Belo Horizonte as type locality and mentioned that the type specimen was deposited in the collections of the Instituto Ezequiel Dias. Attempts to find the type specimen of $T$. serrulatus proved to be vain, suggesting that the specimen was damaged or lost. This situation conducted Lourenço and Eickstedt [47] to designate a neotype (a replacement type), based on material equally collected in Belo Horizonte (as recommended by the International Code of Zoological Nomenclature). This neotype was deposited in the collections of the Instituto Butantan in São Paulo, but was probably destroyed during the recent fire incident that took place in the collection's building of this institution [48, 49].

Today it is well known that the geographic distribution of T. serrulatus (the Brazilian yellow scorpion) has expanded considerably over the Southeast, South and Central

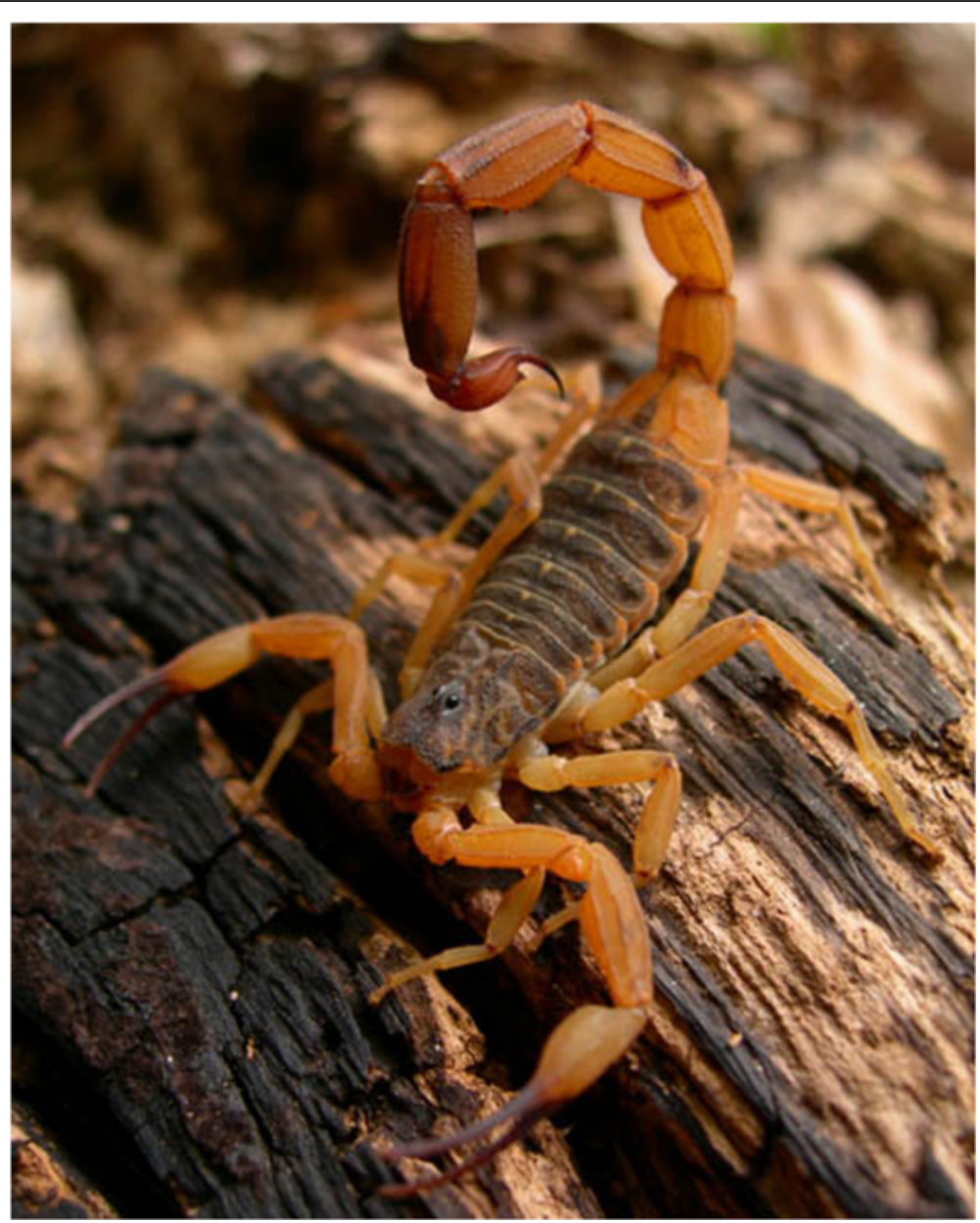

Fig. 5 Female of Tityus serrulatus from the state of Bahia (photo courtesy of T. J. Porto) 
regions of Brazil (Fig. 6). Everyone also agrees that this species poses major health problems due to its rapid expansion in urban areas, rapid proliferation and great toxicity. However, the possible history of the evolution of T. serrulatus in Brazil, and even in parts of South America, is, to say the least, singular.

Scorpionism was known in Brazil in the end of the $19^{\text {th }}$ century and has been documented since then. The first comprehensive study of the phenomenon was the one by Maurano [50], who concentrated his observations on Tityus bahiensis, the second most noxious scorpion species in Brazil.

Nevertheless, before the contribution by Maurano [50], not much had appeared in the literature about scorpion problems in Brazil. This particularity seems curious when compared to the enormous health problems caused by scorpions currently. In addition, in other countries such as Mexico, where scorpionism is also a severe health problem, this phenomenon has been cited regularly in the literature since the $16^{\text {th }}$ century [51]. More recent studies include those by Clavigero [52] and Duges [53]. Moreover, the scientific and medical aspects of this issue have been the subject of detailed studies since the beginning of the century [54-56].

The fact that the work carried out by Maurano [50] in 1915 dealt only with Tityus bahiensis and that antivenom serum against this species has been produced since 1915 is probably related to the fact that Tityus serrulatus, which was only described in 1922, was much less common in the early $20^{\text {th }}$ century than today. However, one major question arises: how can such a common species as $T$. serrulatus - well known since the 1920s (according to Magalhães [57], his laboratory in Minas Gerais received 600.000 specimens between 1922 and 1952) - had not been observed previously and was described rather later than other common species?

Even if the main particularity of T. serrulatus has always been its noxious character and medical importance, one other point remained enigmatic during several years: the absence of males from all known populations. The question was finally answered by Matthiesen [58], who first demonstrated that this species could reproduce by parthenogenesis. This phenomenon was later confirmed for a few other species of scorpions, but remains rare [59]. Tityus serrulatus was usually considered an obligate parthenogenetic species, but some isolated bisexual populations have finally been detected $[60,61]$. However, bisexual populations appear to be extremely marginal within the present geographic distribution of the species, which suggests their possible elimination from most, if not all, the unpredictable environments occupied by $T$. serrulatus [62, 63].

It was previously suggested by Lourenço and CloudsleyThompson [60] that T. serrulatus could be closely related to Tityus stigmurus (Thorell), a bisexual species with a range of distribution further to northeastern states of Brazil. However, the final discovery of sexual populations of T. serrulatus invalidated this hypothesis. On the other

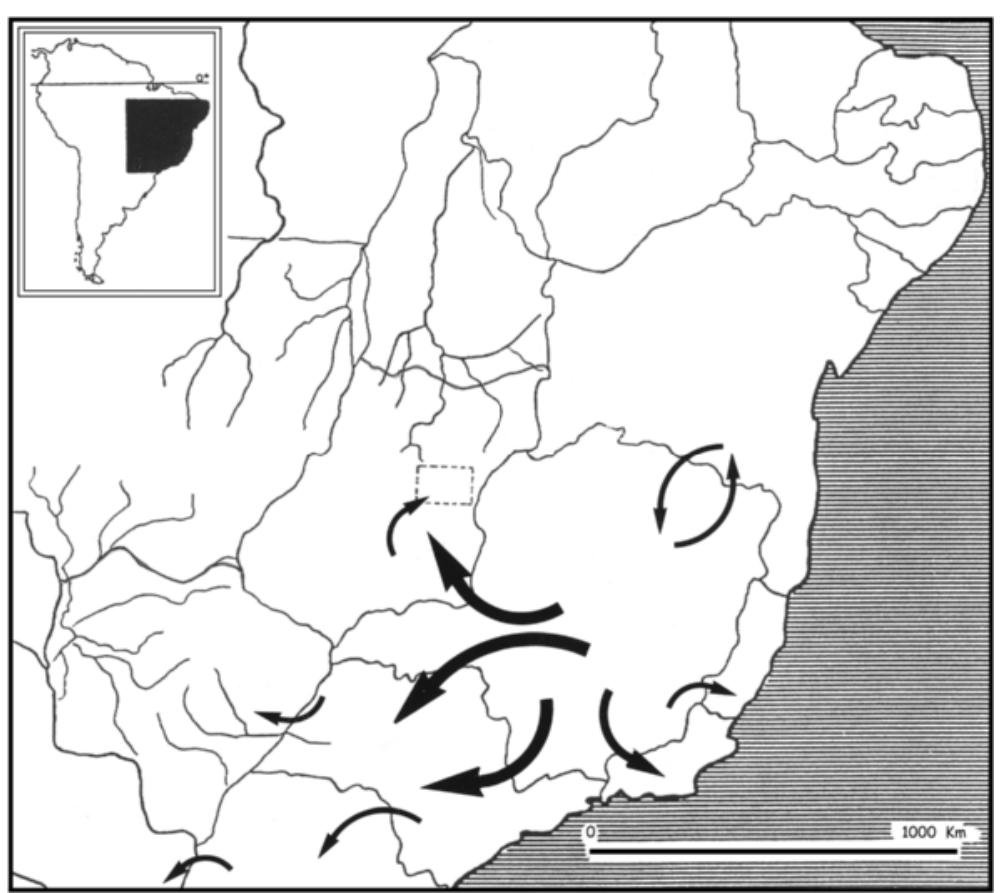

Fig. 6 Map of the Southeast and Central regions of Brazil. Arrows illustrate the expansion of T. serrulatus over a period of several decades 
hand, a previously described and more southern distribution of T. stigmurus - which resembles the present geographic range of $T$. serrulatus - was accepted by some authors [11, 64]. By checking the personal notes of J. Vellard and some of the material that he collected in the late 1920s, it can be proposed that T. stigmurus was a possible common species in the state of Minas Gerais and south of Goiás, at least until the $19^{\text {th }}$ century. It is possible, therefore, that both species have been misidentified during several years, since Tityus stigmurus was described by Thorell [65].

The precise period during which parthenogenenesis appeared de novo within the population of T. serrulatus is difficult to establish. However, the presence of this species in Minas Gerais before the beginning of the $18^{\text {th }}$ century was probably extremely inconspicuous. At the beginning of the $18^{\text {th }}$ century, an important development was engendered by the Portuguese (especially in their search for gold) with the foundation of towns such as Curral d'El Rei and Vila Rica de Ouro Preto [66]. Previously, metaclimax environments suffered human impact, turning them into disclimax. This favored the previously discrete parthenogenetic population of Tityus serrulatus, extremely opportunistic, and 'encouraged' it to explore the newly created disclimax habitats. The expansion of human colonization towards west and north resulted in a significant regression of the original bisexuals, which were gradually replaced by the parthenogenetic population.

One of the characteristics of opportunistic and parthenogenetic species is their density-independent population regulation, whereas equilibrium species show densitydependent population regulation. This is the reason why, in both old and recent literature describing scorpionism in Brazil, we find the expression of 'population explosions', corresponding to the local word surtos (from the Latin surctu $=>$ surrectu: 'to appear'), which reflects the type of population fluctuation observed in T. serrulatus.

The mechanism of selection of species that have low ecological plasticity acts indistinctly on noxious and innocuous species. Ecological plasticity is not associated with the presence of toxic venom. Numerous noxious equilibrium species are selected negatively by human activities on the environment.

The positive selection of noxious opportunistic species is directly associated with human activity. Let us suppose that, in a profoundly modified environment, as in several 'artificial' cities of Brazil, the human population begins to increase rapidly. Within a short period, the three main factors needed to transform the region into an important center of scorpionism are assembled:

1. Large-scale demographic expansion of the human population.
2. Rapid expansion of the noxious opportunistic scorpion population that will soon occupy all the empty niches left by the regression or extinction of the equilibrium species. In many cases, the opportunistic species changes its behavior and begins to live inside human dwellings.

3. The overlapping of a large human population with a large population of noxious scorpions will increase enormously the probability of incidents of scorpionism. This situation is characteristic of certain regions in Brazil.

The parthenogenetic $T$. serrulatus usually colonizes urban areas (cities and towns), and can easily be transported by human agency from old to new cities. Brasilia, for instance, has been invaded and was colonized by $T$. serrulatus in less than 15-20 years [67]. What has been observed in the region of Brasilia is certainly also taking place in other cities and towns of different regions in Brazil (Fig. 6).

Curiously, however, the absolute number of noxious species seems to remain stable. Over a period of many years, several authors have suggested that only a limited number of species can be really dangerous to humans [68]. I suggest that this number is, in fact, much higher in nature, but that many noxious species are never in close contact with humans. In very large natural regions such as Amazonia, human populations were scarce for centuries, and only in recent years a rapid expansion of colonization has occurred, with dramatic destruction of the natural environment. It is quite possible that several species of the genus Tityus in Amazonia may be highly toxic. Isolated cases of lethal incidents have been observed after stings by Tityus metuendus Pocock and Tityus obscurus Gervais [69]. Such as many others, however, these species are probably equilibrium species and will be partially or completely selected by the destruction of their environment before human populations become large and vulnerable to them.

Morphologically, Tityus serrulatus is well known. The following general description is proposed: scorpions of medium size ranging from 55 to $70 \mathrm{~mm}$ in total length, general coloration yellowish with the presence of dark confluent spots over the tergites. Metasomal segments I to $\mathrm{V}$ are yellowish with lateral and ventral areas blackish. The dorsal keels of segments III and IV have the posterior granules modified as spines, which vary from 4 to 6 in number. These form a serrula (Fig. 7) which is the origin of the Latin name of the species, T. serrulatus. Dentate margins of pedipalpchela fingers are composed of 13 to 17 oblique rows of granules. Telson has a long curved aculeus; the subaculear tooth is strong and spinoid. Pectines have 18 to 25 teeth. 


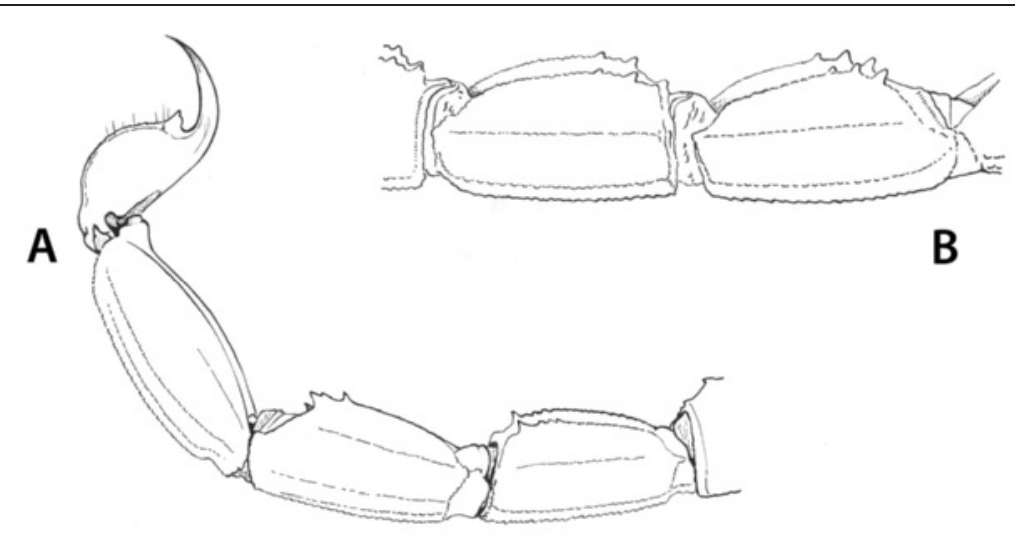

Fig. 7 Serrulas present on the dorsal carinae of metasomal segments of Tityus species: (a) Tityus kuryi Lourenço and (b) T. serrulatus

Geographical distribution: the species is found in the southeastern and central states of Brazil: Minas Gerais, São Paulo, Goiás, Federal District and possibly Mato Grosso and Rondônia. It was also recorded in Argentina and Bolivia.

\section{Tityus costatus (Karsch, 1879)}

Tityus costatus (Fig. 8) was described by Karsch [70], based on specimens collected in the state of Rio de Janeiro. Although this species does not have an infamous reputation, it may be responsible for several incidents in the coastal regions of Brazil. These incidents are certainly misidentified and, in several cases, attributed to $T$. bahiensis or T. serrulatus. Not much is known about the venom or toxins produced by this species. Nonetheless, in an already old publication Bücherl and Pucca [71] suggested that it could have a strong effect on mice.

In their study on Tityus serrulatus venom, ChavezOlórtegui et al. [72] refer to an interesting historical description, concerning the first record of scorpion envenoming in Brazil. This was described by Jean de Léry [73], a French Calvinist who took part in the French expedition - commanded by André Villeigagnon that aimed to establish a colony in Brazil. This colony should be 'La France Antarctique', and the group arrived at the Guanabara Bay, today Rio de Janeiro. According to Prof. Carlos R. Diniz (who presented a communication in the $1^{\text {st }}$ International Congress on Envenomations and Their Treatments, which took place in the Pasteur Institute, Paris, in 1995), the scorpion responsible for this incident could only be Tityus serrulatus.

The description by Jean de Léry is rather vague and could be associated with different species of scorpions. However, having into account the described symptoms, one can presume that the incident was caused by a buthid scorpion. The description of J. de Léry can be summarized as follows: 'In Brazil, by moving the stones or grabbing the ground, one can find scorpions which,

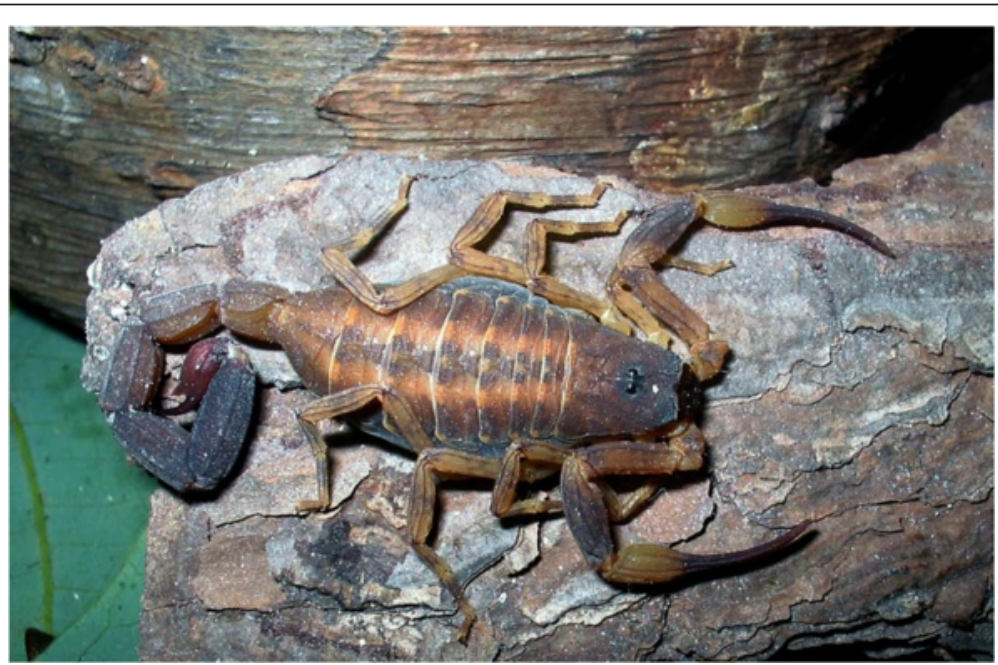

Fig. 8 Female of Tityus costatus, trifasciata form from the state of São Paulo (photo courtesy of T. J. Porto) 
even if smaller than those found in Provence [he was probably referring to Buthus occitanus Amoreux] have their venomous and deadly aculeus, as I could experience myself. The animal seems to be attracted to clean objects. After I had washed my cotton hammock, I prepared to lay down as the natives do, without noticing that a scorpion was hidden in the lining. It stung me on the thumb of my left hand, which swelled rapidly. The venom would have spread throughout my body if I had not been treated by an apothecary, who preserved scorpions in a bottle containing oil. Despite the remedy, reputed to be the most effective in this case, I was in such a state for twenty-four hours that I could not stand the terrible pain. When the local savages are stung by a scorpion, they use the same remedy, which means they kill the scorpion and immediately squash it on the stung area' [73].

For a better illustration, the original description made by Jean de Léry in Old French is included herein:

J'adjousteray encores, qu'en remuant la terre et dessous les pierres, en nostre contrée du Bresil, on trouve des scorpions lesquels, combien qu'ils soyent beaucoup plus petits que ceux qu'on voit en Provence, neantmoins pour cela ne laissent pas, comme je l'ay experimenté, d'avoir leurs pointures venimeuses et mortelles. Comme ainsi soit doncques que cest animal cerche les choses nettes, advint qu'apres que j'eu un jour fait blanchir mon lict de cotton, l'ayant rependu en l'air, à la façon des sauvages, il y eut un scorpion qui s'estant caché dans le repli: ainsi que je me voulu coucher, et sans que je le visse, me picqua au grand doigt de la main gauche, laquelle fut si soudainement enflée, que si en diligence je n'eusse eu recours à l'un de nos Apothicaires (lequel en tenant de morts dans une phiole, avec de l'huile, m'en appliqua un sur le doigt), il n'y a point de doute que le venin ne se fust incontinent espanché par tout le corps. Et de fait, nonobstant ce remede, lequel neantmoins on estime le plus souverain à ce mal, la contagion fut si grande, que je demeuray l'espace de vingt-quatre heures en telle destresse, que de la vehemence de la douleur je ne me pouvois contenir. Les sauvages aussi estans piquez de ces scorpions, s'ils les peuvent prendre, usent de la mesme recepte, assavoir de les tuer et escacher soudain sur la partie offense [73].

Most obviously, the incident described by J. de Léry cannot be attributed to $T$. serrulatus, which was not a native element of the Rio de Janeiro region on the $16^{\text {th }}$ century. Only several centuries later this species colonized this part of Brazil.

Instead, Tityus costatus is an autochtonous element of the Brazilian Atlantic forest, and most certainly was a common species in the area when the French expedition took place, from 1555 to 1558 . Consequently, this species is the perfect suspect of being the responsible of the first reported scorpion incident in Brazil.

Morphologically, Tityus costatus is a rather poorly known species by non-experts. For a long time it remained inadequately characterized. Lourenço [15] stated that it was difficult to distinguish T. costatus from Tityus trivittatus dorsomaculatus Lutz \& Mello. Studies on additional material from several localities in the Atlantic Forest, from the states of Espírito Santo to Rio Grande do Sul, establish the existence of a mosaic pattern of polymorphism in Tityus costatus [32]. The two nominal species are only different morphs of one single species. $T$. costatus is defined as a maculata form and T. dorsomaculatus as a trifasciata form.

The following brief description of its distinguishing characteristics is offered: scorpions of medium size, from 50 to $70 \mathrm{~mm}$ in total length. The general coloration is yellowish brown with three longitudinal stripes over the tergites in the trisfaciata form or with blackish tergites in the maculata form. Metasomal segments I to III are yellowish; IV and V are reddish; and presence of strong spots ventrally. Pedipalps are yellowish to reddish-yellow and strongly spotted; fingers are very dark. Legs are yellowish with diffuse fuscous spots. Dentate margins of pedipalp-chela fingers are composed of 15 to 17 oblique rows of granules. Telson has a long curved aculeus; subaculear tooth is strong and spinoid. Pectines have 16 to 20 teeth.

The geographical distribution includes the states of Espírito Santo, Minas Gerais ('Zona da Mata'), São Paulo, and Paraná to Rio Grande do Sul. The maculata form is generally found in altitudes above $1000 \mathrm{~m}$, whereas the trifasciata form occurs at lower altitudes down to the sea level (Fig. 2).

\section{Competing interests}

The author declares that there are no competing interests.

\section{Acknowledgments}

I am most grateful to Prof. Maria Elena de Lima, Federal University of Minas Gerais, Belo Horizonte, for her invitation to contribute to the present thematic series. To Miss Elise-Anne Leguin, Muséum national d'Histoire naturelle, Paris, who helped me with the preparation of maps and photos. To Mr. Tiago J. Porto, Federal University of Bahia, Salvador, for the permission to use some of his scorpion photos.

Received: 10 December 2014 Accepted: 18 May 2015

Published online: 10 June 2015

\section{References}

1. Polis GA. Ecology. In: Polis GA, editor. The biology of scorpions. Stanford: Stanford University Press; 1990. 247-293.

2. Loret E, Hammock B. Structure and neurotoxicity of venoms. In: Brownell P, Polis GA, editors. Scorpion biology and research. New York: Oxford University Press; 2001. p. 204-33.

3. De Lima ME, Martin MF, Diniz CR, Rochat H. Tityus serrulatus toxin VII bears pharmacological properties of both beta-toxin and insect toxin from scorpion venoms. Biochem Biophys Res Commun. 1986;139(1):296-302. 
4. McCormick SJ, Polis GA. Prey, predators, and parasites. In: Polis GA, editor. The biology of scorpions. California: Stanford University Press; 1990. p. 294-320.

5. Fet V, Gantenbein B, Gromov AV, Lowe G, Lourenço WR. The first molecular phylogeny of Buthidae (Scorpiones). Euscorpius. 2003;4:1-10.

6. Koch CL. Die Arachniden. Nürnberg: C. H. Zeh'sche Buchhandlung; 1836; 5(1-5):17-104

7. Spix JB, Martius CFP. Delectus animalium articulatorum, quae in itinere per Brasiliam annis MDCCCXVIII-MDCCCXX [...]. Monachii: prostat apud, lipsiae apud frid., fleischer in comm; 1830.

8. Linnaeus C, C. von Linné. Systema Naturae per regna tria naturae: secundum classes, ordines, genera, species, cum characteribus, differentiis, synonymis, locis. 10th ed. Stockholm: Impensis Direct. Laurentii Salvii; 1758. p. 821. Scorpions: Pp. 624-625.

9. Kraepelin K. Scorpiones und Pedipalpi. In: Dahl F, editor. Das tierreich, 8 (Arachnoidea): Herausgegeben von der deutschen zoologischen gesellschaft. Berlin: Verlag von R. Friedländer und Sohn; 1899. p. 1-265.

10. Kraepelin K. Neue Beiträge zur Systematik der Gliederspinnen. In: Mitteilungen aus dem Naturhistorischen Museum 2. Hamburg: Beiheft zum Jahrbuch der Hamburgischen wissenschaftlichen Anstalten; 1911. 28(2):59-107.

11. Mello-Campos O. Os escorpiões brasileiros. Mem Inst Oswaldo Cruz. 1924;17(2):237-301.

12. Mello-Leitão C. Divisão e distribuição do gênero Tityus Koch. An Acad Bras Ciênc. 1931;3(3):119-50.

13. Mello-Leitão C. Revisão do gênero Tityus. Physis B Aires. 1939;17:57-76.

14. Mello-Leitão C. Escorpiões sul-americanos. Arq Mus Nac Rio de Janeiro. 1945; $40: 7-468$

15. Lourenço WR. Contribution à la connaissance systématique des scorpions appartenant au complexe Tityus trivittatus Kraepelin, 1898 (Buthidae). Bull Mus Nat Hist Nat, Paris. 1980;2(A3):793-843. 4e série.

16. Lourenço WR. Sur la systématique des scorpions appartenant au complexe Tityus stigmurus (Thorell, 1877) (Buthidae). Rev Bras Biol. 1981;41(2):351-62.

17. Lourenço WR. La véritable identité de Tityus bahiensis (Perty, 1834). Description de Tityus eickstedtae n. sp. (Scorpiones, Buthidae). Rev Arachnol. 1982;4:93-105.

18. Lourenço WR. Analyse taxonomique des scorpions du groupe Tityus clathratus Koch, 1845 (Scorpiones, Buthidae). Bull Mus Nat Hist Nat, Paris. 1984;6(A2):349-60. 4e série.

19. Lourenço WR. Etude systématique de quelques espèces appartenant au complexe Tityus forcipula (Gervais, 1844) (Scorpiones, Buthidae). Bull Mus Nat Hist Nat, Paris. 1984;6(A3):729-39. 4e série.

20. Lourenço WR, Maury EA. Contribution à la connaissance systématique des scorpions appartenant au 'complexe' Tityus bolivianus Kraepelin, 1895 (Scorpiones, Buthidae). Rev Arachnol. 1985;6(3):107-26.

21. Lourenço WR, Eickstedt VRD. Contribuição ao conhecimento taxonômico dos escorpiões associados ao grupo Tityus melanostictus Pocock, 1893 (Scorpiones, Buthidae). Mem Inst Butantan. 1987;49(3):87-95.

22. Lourenço WR. La faune des scorpions de I'Equateur. I. Les Buthidae. systématique et biogéographie. Rev Suisse Zool. 1988;95(3):681-7.

23. Lourenço WR. Synopsis de la faune scorpionique de la région de Manaus, Etat d'Amazonas, Brésil, avec description de deux nouvelles espèces. Amazoniana. 1988;10(3):327-37.

24. Lourenço WR. Les scorpions (Chelicerata) de Colombie. II. Les faunes des régions de Santa Marta et de la Cordillère Orientale. Approche biogéographique. Senckenbergiana Biol. 1991;7(4-6):275-88.

25. Lourenço WR. Biogéographie des espèces du groupe naturel 'Tityus clathratus' (Chelicerata, Scorpiones, Buthidae). Bull Mus Nat Hist Nat, Paris. 1992;14(A2):473-81. 4e série.

26. Lourenço WR. Scorpions (Chelicerata) de Colombie. VI. Quatre nouvelles espèces de Buthidae des régions amazonienne, sud-pacifique et de la Cordillère Orientale. Rev Acad Colombiana Cienc Exact Fís Natur. 1994;19(73):387-92.

27. Lourenço WR. Synopsis of the Colombian species of Tityus Koch (Chelicerata, Scorpiones, Buthidae), with descriptions of three new species. J Nat Hist. 2000;34(3):449-61.

28. Lourenço WR. Diversité de la faune scorpionique de la région amazonienne; centres d'endémisme; nouvel appui a la théorie des refuges forestiers du Pléistocène. Amazoniana. 1986;9(4):559-80.

29. Lourenço WR. Les modèles évolutifs des scorpions néotropicaux et la théorie des refuges forestiers du Pléistocène. C R Soc Biogéogr. 1987;63(3):75-88.

30. Lourenço WR. Diversité biologique et modalités de la spéciation chez les scorpions amazoniens; Tityus silvestris Pocock, un cas particulier de polymorphisme. C R Acad Sci, Paris. 1988;306:463-6. série 3.
31. Lourenço WR. Scorpion diversity in tropical South America: implication for conservation programs. In: Brownell P, Polis GA, editors. Scorpion biology and research. Oxford: Oxford University Press; 2001. p. 406-16.

32. Lourenço WR, Eickstedt VRD. Considerações sobre a sistemática de Tityus costatus (Karsch, 1879), provável espécie polimórfica de escorpião da Floresta Atlântica do Brasil (Scorpiones, Buthidae). Iheringia Sér Zool. 1988;68:3-11.

33. González-Sponga MA. Guía para identificar escorpiones de Venezuela. Caracas: Cuadernos Lagoven; 1996.

34. Lourenço WR. Scorpions of Brazil. Paris: Les Editions de L'If; 2002.

35. Lourenço WR. Description of a new species of Tityus (Scorpiones, Buthidae) from Serra da Jurema in the state of Bahia, Brazil. Rev Iber Aracnol. 2003;7:109-15.

36. Lourenço WR. Description of a new species of Tityus (Scorpiones, Buthidae) from Serra do Cipo in the state of Minas Gerais. Brazil Rev Suisse Zool. 2003;110(2):427-35.

37. Lourenço WR. Scorpion diversity and endemism in the Rio Negro region of Brazilian Amazonia, with the description of two new species of Tityus C. L. Koch (Scorpiones, Buthidae). Amazoniana. 2005;18(3-4):203-13.

38. Lourenço WR. Further considerations on Tityus (Archaeotityus) clathratus C. L. Koch, 1844 and description of two associated new species (Scorpiones, Buthidae). Bol Soc Entomol Arag. 2012;50:277-83.

39. Lourenço WR. A new species of Tityus C. L. Koch, 1836 (Scorpiones, Buthidae) from the island of Martinique, Lesser Antilles. Arthrop Sel. 2013;22(3):227-31.

40. Lourenço WR, Ythier E. The remarkable scorpion diversity in the Ecuadorian Andes and description of a new species of Tityus C. L. Koch, 1836 (Scorpiones, Buthidae). ZooKeys. 2013;307:1-13. [http://zookeys.pensoft.net/ articles.php?id=3208\&display_type=list\&element_type=9]

41. Lourenço WR. Origines et affinités des scorpions des Grandes Antilles: Le cas particulier des éléments de la famille des Buthidae. Biogeographica (Paris). 1999;75(3):131-44.

42. Armas LF, Abud-Antun AJ: Adiciones al género Tityus C. L. Koch, 1836 en República Dominicana, con la descripción de dos especies nuevas (Scorpiones: Buthidae). Rev Ibér Aracnol. 2004;10:53-64. [http://www.sea-entomologia.org/ Publicaciones/RevistalbericaAracnologia/RIA10/R10-005-053.pdf]

43. Lourenço WR, Pézier A. Addition to the scorpion fauna of the Manaus region (Brazil), with a description of two new species of Tityus from the canopy. Amazoniana. 2002;17(1-2):177-86.

44. Lourenço WR. Nouvelle proposition de découpage sous-générique du genre Tityus C. L. Koch, 1836 (Scorpiones, Buthidae). Bol Soc Entomol Arag. 2006;39:55-67.

45. Papavero N. Essays on the history of Neotropical dipterology with special reference to collectors (1750-1905), vol. 1. São Paulo: Museu de Zoologia, Universidade de São Paulo; 1971. p. 216.

46. Lutz A, Mello O. Descrição de 5 espécies brasileiras dos gêneros Tityus e Rhopalurus. Folha Méd. 1922;3(4):25-6.

47. Lourenço WR, Eickstedt VRD. A propósito da indicação de um neótipo para Tityus serrulatus Lutz e Mello, 1922 (Scorpiones, Buthidae). Mem Inst Butantan. 1981;44-45:181-90.

48. Warrell DA, Theakston RDG, Wüster W. Destruction of the collection of reptiles and arthropods at Butantan Institute: a view from the United Kingdom. J Venom Anim Toxins incl Trop Dis. 2010;16(4):534-6 [http://www.scielo.br/ scielo.php?script=sci_arttext\&pid=\$1678-91992010000400003\&lng=en]

49. De Lima ME. "Vitalis Brazilis", burning embers, beyond the ashes, at the Butantan Institute. J Venom Anim Toxins incl Trop Dis. 2010;16(3):400-1 [http://www.scielo.br/scielo.php?script=sci_arttext\&pid=\$1678-91992010 $000300005 \& \operatorname{lng}=e n]$

50. Maurano HR. Do escorpionismo. PhD Thesis. Universidade Federal do Rio de Janeiro. Rio de Janeiro: Faculdade de Medicina; 1915:267.

51. Cardenas J. Primera parte de los problemas y secretos maravillosos de las Indias. 2nd ed. México: Pedro Ocharte; 1591. p. 458.

52. Clavigero FJ. Historia antigua de México y de su conquista. Translation from the Italian. 1883rd ed. Mexico: Dublan y Cia; 1780.

53. Duges A. Elementos de Zoologia. Mexico city: Secretaria de Fomento; 1884. p. 520

54. Jackson HV. A preliminary study of the poisonous scorpions including a review of some recent literature and personal experiences. Interstate Med J. 1910;17(7):485-98.

55. Baerg WJ. Some poisonous arthropods of North and Central America. 4th Int Cong Ent Ithaca. 1929;2:418-38. 
56. Mazzoti L, Bravo-Becherelle MA. Scorpionism in the Mexican Republic. In: Venomous and poisonous animals and noxious plants of the Pacific area. Oxford: Pergamon Press; 1963. p. 119-31.

57. Magalhães O. Escorpionismo. Bras Méd. 1953;18-25:19-23.

58. Matthiesen FA. Parthenogenesis in scorpions. Evolution. 1962;16(2):255-6.

59. Lourenço WR. Parthenogenesis in scorpions: Some history - new data. J Venom Anim Toxins ind Trop Dis. 2008;14(1):19-44 [http://www.scielo.br/ scielo.php?script=sci_arttext\&pid=S1678-91992008000100003\&lng=en\&nrm=iso]

60. Lourenço WR, Cloudsley-Thompson JL. Discovery of the sexual population of 'Tityus serrulatus', alias the 'confluenciata' form within the complex 'Tityus stigmurus' (Thorell) (Scorpiones, Buthidae). J Arachnol. 1999;27(1):154-8.

61. De Souza CAR, Candido DM, Lucas SM, Brescovit AD. On the Tityus stigmurus complex (Scorpiones, Buthidae). Zootaxa. 1987;2009:1-38.

62. Lourenço WR, Cuellar O. Scorpions, Scorpionism, life history strategies and parthenogenesis. J Venom Anim Toxins. 1995;1(2):50-64 [http://www.scielo.br/ scielo.php?script=sci_arttext\&pid=S0104-79301995000200002]

63. Lourenço WR, Cloudsley-Thompson JL, Cuellar O, Eickstedt VRD, Barraviera B, Knox MB. The evolution of scorpionism in Brazil in recent years. J Venom Anim Toxins. 1996;2(2):121-34 [http://www.scielo.br/scielo.php?pid=S010479301996000200005\&script=sci_arttext]

64. Vellard J. Scorpions. In: Mission scientifique au Goyaz et au Rio Araguaya. Mém Soc Zool France. 1932, 29(6):539-556.

65. Thorell T. Études scorpiologiques. Atti della Società Italiana di Scienze Naturali. 1876;19:75-272.

66. Leloup Y. Les villes du Minas Gerais. Paris: Institut des hautes études des I'Amérique Latine; 1970. p. 1-301 [Series: Travaux \& mémories de Institut des hautes études des l'Amérique Latine, no. 25].

67. Lourenço WR, Knox MB, Yoshizawa MAC. L'invasion d'une communauté à le stade initial d'une succession secondaire par une espèce parthénogénétique de scorpion. Biogeographica. 1994;70(2):77-91.

68. Simard JM, Watt DD. Venoms and toxins. In: Polis GA, editor. The biology of scorpions. Stanford: Stanford University Press; 1990. p. 414-44.

69. Lourenço WR. The distribution of noxious species of scorpions in Brazilian Amazonia: the genus Tityus C. L. Koch, 1836, subgenus Atreus Gervais, 1843 (Scorpiones, Buthidae). Entomol Mitt Zool Mus Hamburg. 2011;15(185):287-301.

70. Karsch F. Scorpionologische Beiträge - Part II. Mitt Münch Entomol Ver 1879;3:97-136.

71. Bücherl WN. Pucca 1956. Escorpiões e escorpionismo no Brasil. III. Titulação por meio de camundongos das peçonhas de Tityus costatus (Karsch), Tityus trivittatus Kraepelin, 1898 e Bothriurus bonariensis (Koch). Mem Inst Butantan. 1842:27:41-50

72. Chavez-Olórtegui CA, Moreira Ferreira M, Nascimento Cordeiro M, Maria WS, Richardson M, Diniz CR. Immunological and chemical properties of non-toxic protein purified from the venom of the scorpion Tityus serrulatus (Lutz and Mello-Campos, 1922). In: Bon C, Goyffon M, editors. Envenomings and their treatments. Lyon: Editions Fondation Marcel Mérieux; 1996. p. 183-95.

73. De Léry J. Histoire d'un voyage fait en la terre du Brésil, autrement dite Amerique. Paris: Alphonse Lemerre Editeur; 1580. p. 103.

\section{Submit your next manuscript to BioMed Central and take full advantage of:}

- Convenient online submission

- Thorough peer review

- No space constraints or color figure charges

- Immediate publication on acceptance

- Inclusion in PubMed, CAS, Scopus and Google Scholar

- Research which is freely available for redistribution

Submit your manuscript at www.biomedcentral.com/submit 